\title{
CALCRETES OF THE BAURU GROUP (CRETACEOUS), BRAZIL: PETROLOGY AND GEOLOGICAL SIGNIFICANCE
}

\author{
KENITIRO SUGUIO \\ Instituto de Geociências, USP
}

\author{
JOSE H. BARCELOS \\ Instituto de Geociências e \\ Ciências Exatas, UNESP
}

\begin{abstract}
The calcareous sandstones and sandy limestones of the Bauru Group have been frequently mentioned in geologic literature of Brazil since the beginning of this century, but this Group has only recently been studied in detail and reliably divided into formations about two years ago. Only in 1973 was a detailed investigation carried out especially focusing on the petrologic, chemical and isotopic properties of these sediments, which for the first time were interpreted as calcretes. This paper reinterprets these petrologic studies and their geological significance in the light of recent literature on the calcretes in the world, and the recent revision of Bauru Group stratigraphy.
\end{abstract}

\section{RESUMO}

Os arenitos calcíticos e os calcários arenosos do Grupo Bauru têm sido freqüentemente mencionados na literatura geológica brasileira desde o início deste século, mas este grupo foi só recentemente estudado em detalhe e apropriadamente subdividido em formaçðes há cerca de dois anos. Somente em 1973 foi executada uma pesquisa detalhada, enfocando especialmente as propriedades petrologicas, químicas e isotópicas desses sedimentos, quando foram pela primeira vez interpretados como calcretes. Neste trabalho, os estudos petrológicos e seus significados geológicos são reinterpretados a luz da literatura moderna sobre os calcretes no mundo e da recente revisão estratigráfica do Grupo Bauru.

\section{INTRODUCTION}

Calcretes are continental materials composed predominantly of powdery to nodular calcium carbonate, cementing to a greater or lesser degree quantities of soil or rock, primarily within the vadose zone (GOUDIE, 1975:3). They are known by several names: caliche (United States), croûte calcaire (France), nari (Israel), etc. However, as a term of general utility, calcrete is preferred because it has few local connotations.

The recognition of fossil calcretes in ancient sedimentary sequences, as in the Marilia Formation (Upper Cretaceous of southern Brazil) of the Bauru Group holds considerable interest for paleoenvironmental reconstructions for two main reasons. First, calcretes are presently extensively distributed in hot semi-arid regions (GOUDIE, 1973), which supports their use as climatic indicators. Second, they seem to indicate subaerial exposure (MULTER and HOFFMEISTER, 1968, DUNHAM, 1969 and JAMES, 1972), though some authors (ELIAS, 1948 and KENDALL, 1969) have interpreted them as of algal or stromatolitic origin and related to lacustrine, lagoonal or marine environments.

Through the examination of the available literature and the description of thin sections, polished sections and hand specimens of modern calcretes, GOUDIE (1975:4) put forward some general characteristics of calcretes, useful in the recognition of ancient deposits, such as: 
SUGUIO, K. \& BARCELOS, J.H.

a) Laminar features - These are found in the surficial portions (topmost 1 to $3 \mathrm{~cm}$ ) and are characterized in section by laminations about $0.06 \mathrm{~mm}$ thick. When arranged in wavy, convolute bands, they have often been confused with algal structures. The laminar structure can result from alternate layers of more or less Fe-oxide stained bands or from differences in calcite crystal size (NAGTEGAAL, 1969). Laminar features may not be volumetrically important within common calcrete deposits. However, they have generally drawn much discussion, partly because they are readly visible during field surveys and because of their similarity to stromatolites (ADAMS, 1980: 656).

b) Concentric structures - These are features similar to oolitic structures (JAMES, 1972) and have also been termed pisoids, spherulites and diagenetic ooids. The structures may or may not have detrital mineral grains or fossil fragments as nuclei. When asymmetri$\mathrm{cal}$, there is a tendency for downward directional growth of the outer layers (SWINEFORD et al., 1958 and DUNHAM, 1969), whereas with algal limestones the growth would tend to be upward. Larger than the spherulitic concentric structures are various types of calcrete nodules. In some cases, such nodules formed by the deposition of fine grained carbonate around decaying rootlets, in which case they may be called rhizocretions (KLAP. PA, 1980), not really nodules.

c) Brecciated structures - Brecciation in calcrete occurs at all scales. At macroscale (tens of $\mathrm{cm}$ or larger) it gives rise to pseudoanticlines and wedges (BLANK and TYNES, 1965, REEVES, 1970 and GOUDIE, 1973), while on the mesoscale (a few $\mathrm{cm}$ ) it leads to fragmentation of pebbles (YOUNG, 1964), and, on microscale (fractions of $\mathrm{mm}$ ), it causes clastic debris and individual clastic grains to break up (ROTHROCK, 1925). Brecciated structures in calcretes may form due to crystallization, hydration and/or thermal expansion of various salts.

d) "Floating" and corroded grains - A result of the expansion promoted by calcite recrystallization is the widespread occurrence of "floating" grains which do not exhibit the point-to-point contacts as they show in the parent sediment or soil. During later stage in
Bol. IG, Instituto de Geociẻncias, USP, V. 14:31-47, 1983

the development of calcrete crusts, or hardpan, "floating" grains of quartz or other silicate minerals are strongly corroded by calcite. In very advanced diagenetic stages the calcretes become completely transformed so that virtually nothing remains of the original detrital constituents of the host sediment or soil (NAGTEGAAL, 1969). According to SWINEFORD et al. (1958), it seems probable that small sand-sized areas of coarse calcite observed in many thin sections could represent the former position of detrital grains.

e) Indicators of subaerial exposure As a consequence of the exposure of sediments to subaerial conditions, and their expansion and contraction due to wetting and desiccation, polygonal structures can develop at both the macro and microscale. Also suggestive of a probable subaerial origin is the development of rhizocretions. Incomplete replacement of the pre-existing sediments or soil leads to the preservation of unaltered pockets of sediment or soil.

The limestone deposits characterizing the Marilia Formation (ALMEIDA and BARBOSA, 1953), mostly the Ponte Alta Facies (BARBOSA et al., 1970 and BARCELOS et al., 1981) here named Ponte Alta Member, of the Bauru Group have long been known but were recognized for the first time in 1973 as calcrete and described in detail by SUGUIO. Since then many papers on this subject have been published (SUGUIO et al., 1975, SUGUIO and BARCELOS, 1978 and 1980) and the stratigraphy of the Bauru Group, to which these calcrete deposits belong, has been the subject of extensive investigation. This paper reinterprets SUGUIO's 1973 work in the light of these recent developments.

\section{FIELD CHARACTERISTICS AND DISTRIBUTION}

The Bauru Group calcrete is best developed in the Triângulo Mineiro (south-central Brazil), near Uberaba, Minas Gerais, but is also found in the States of São Paulo, and southern parts of the States of Goiás and Mato Grosso do Sul (Fig. 1).

According to NETTERBERG's calcrete classification (1967), the following types of 

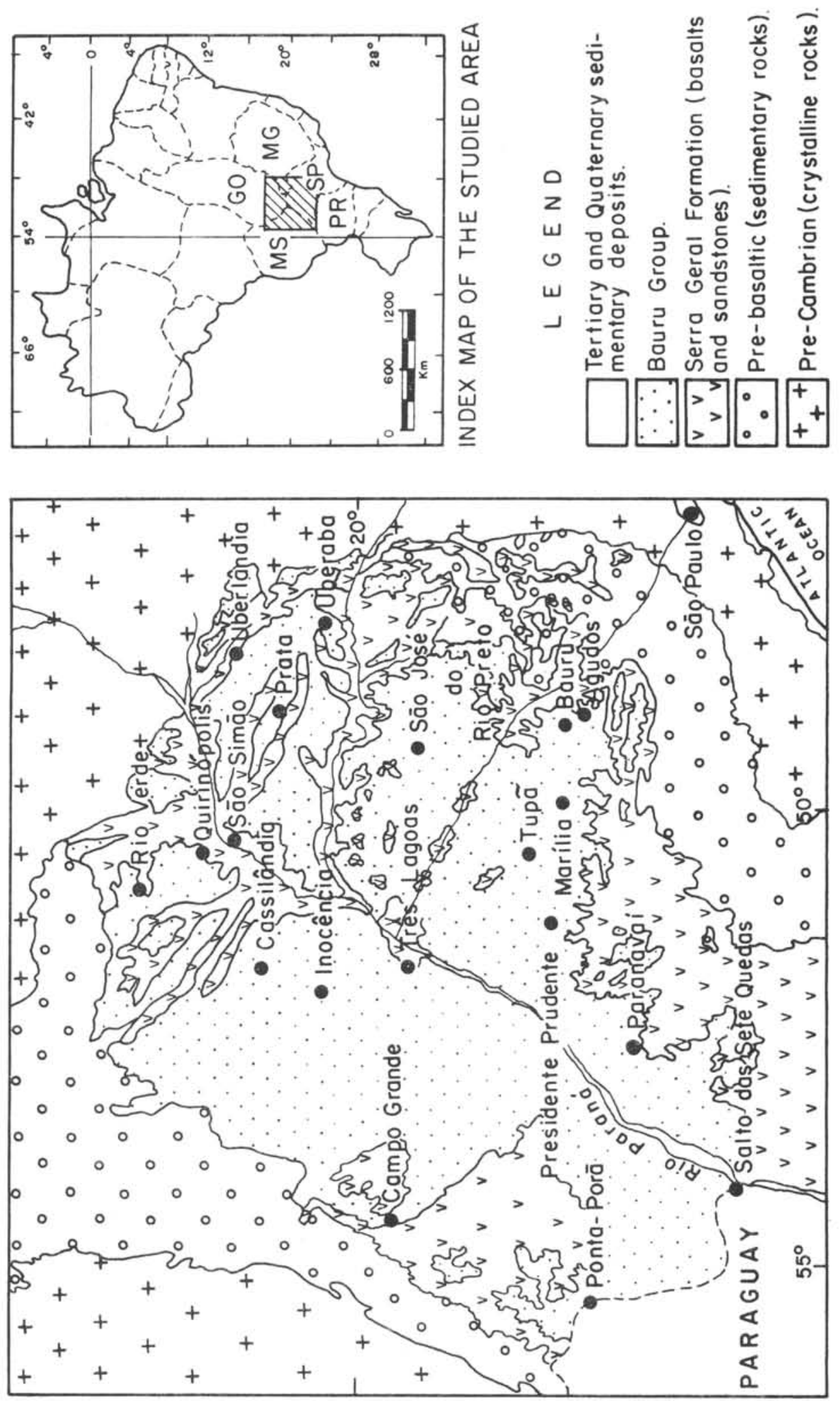

Fig. 1 - Geologic map showing the areal extent of the Bauru Group (Based on Geologic Map of Brazil, Departamento Nacional da Produção Mineral, Rio de Janeiro, 1971). 
calcrete are present in the Bauru Group: calcified soil, nodular calcrete, honeycomb calcrete and hardpan calcrete. The calcified soil and nodular calcretes are not restricted to the Ponte Alta Member and Echaporã Member (name for the first time used here to designate the lithofacies of the Marilia Formation outcropping in the Marilia and Echapora plateaus) of the Marília Formation, frequently being found in other formations of the Bauru Group, such as in the Adamantina Formation as defined by SOARES et al. (1980). Some nodular calcrete of the Marília Formation (Echapora Member) found between Duartina and Gália, in the State of São Paulo, shows evidence of probable reworking after its formation, as it is associated with cut-and-fill structures exhibiting possible unclear cross-bedding.

In the Triângulo Mineiro area, the calcrete seems to be associated laterally and vertically with playa lake limestones, extending from Sacramento to Frutal, over a distance of about $100 \mathrm{~km}$. The average thickness of the hardpan type of calcrete deposits at the village of Ponte Alta (near Uberaba), including the lacustrine limestone, is about $8 \mathrm{~m}$. This value is very small when compared with the maximum recorded thicknesses of $50-60 \mathrm{~m}$ and $47 \mathrm{~m}$ for calcrete profiles from South Africa (GOUDIE, 1973) and at Millstream, Western Australia (DAVIDSON, 1968), respectively. Drilling near Ponte Alta village has revealed the subsurface character of the calcrete deposit (Fig. 2) in the area. Its thickness is very uniform, ranging from a minimum of $7,0 \mathrm{~m}$ (hole 32B) to a maximum of $8.9 \mathrm{~m}$ (hole $38 \mathrm{~B})$, with an average value of $8.0 \mathrm{~m}$. Moreover, the calcrete bed, including the lacustrine limestone, in situated everywhere virtually at the same stratigraphic level and at nearly the same altitude. The conglomeratic portion of the calcrete is known in the Uberaba area under the local name "casco de burro" ("donkey hoof"), which can be described as light coloured (moderate orange pink $=5 \mathrm{YR} 8 / 4$ to yellowish gray $=5 Y 7 / 2$ ) limestones, with sandy impurities and well rounded quartz, quartzite and chert pebbles. Frequently, they are nodular with a mottled appearance due to the presence of the more or less sandy portions. These portions can be enhanced through the action of pluvial leaching, thus acquiring a "brecciated" aspect due to the strong angularity of the sandy spots (Fig. 3). The hardpan calcrete deposits are commonly lenticular, but when better developed, as in the Ponte Alta area, they area associated with purer lacustrine deposits and exploited to make cement. In this area the calcrete deposits run along the cliffs bordering the "chapada", a geomorphological feature characterized by an extensive very flat plateau interrupted only by shallow valleys carved by local drainage.

In the southern parts of the States of Goiás and Mato Grosso do Sul, and in the State of São Paulo, the calcrete is more impure (sandy and pebbly), very frequently silicified, and inferior in both volume and quality to that of the Ponte Alta area. However, it shows some development as in the Agudos (State of São Paulo).

Elsewhere the calcium carbonate occurs as a cement in sandstone and other clastic sedimentary rocks or as irregular nodules scattered within sandy marls or clayey sandstones (Fig. 4). In other places, the calcrete deposits comprise much more impure, calciumcarbonate-cemented conglomerates, occurring as caprocks of residual hills in the Marilia Formation (southern State of Goiás).

\section{LABORATORY STUDIES}

The surface and subsurface calcrete samples from the Bauru Group were examined macroscopically in polished sections, microscopically in thin sections, and chemically by analysing major, minor and trace elements, $\mathrm{HCl}$-insoluble residues and carbon and oxygen isotopes. Geochemical data, including chemical and isotopic compositions, have been discussed elsewhere by SUGUIO et al. (1975), so that only the results of other laboratory analysis are presented here.

\section{MACROSCOPIC DESCRIPTION}

Larger features visible to the naked eye or in hand lens were examined in polished sections of 58 calcrete samples. The commonest feature observed is a mottled pattern produced by both nodular and brecciated structures, although some homogeneous micritic limestones are also found. Macroscopically, the following limestone types can be recognized: 


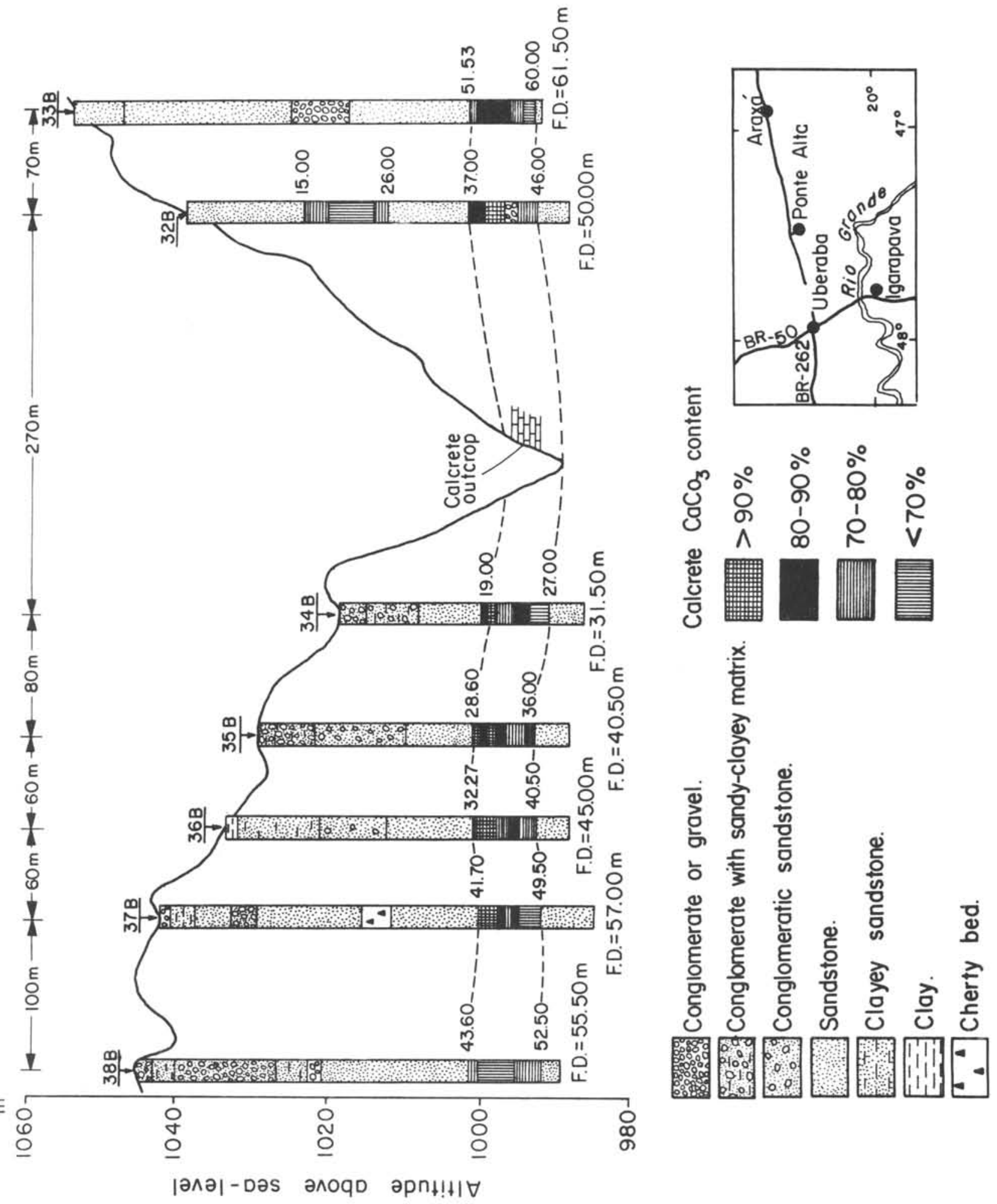

Fig. 2 - Drilling logs in the Buracão area, Ponte Alta village, vicinity of Uberaba (State of Minas Gerais). 


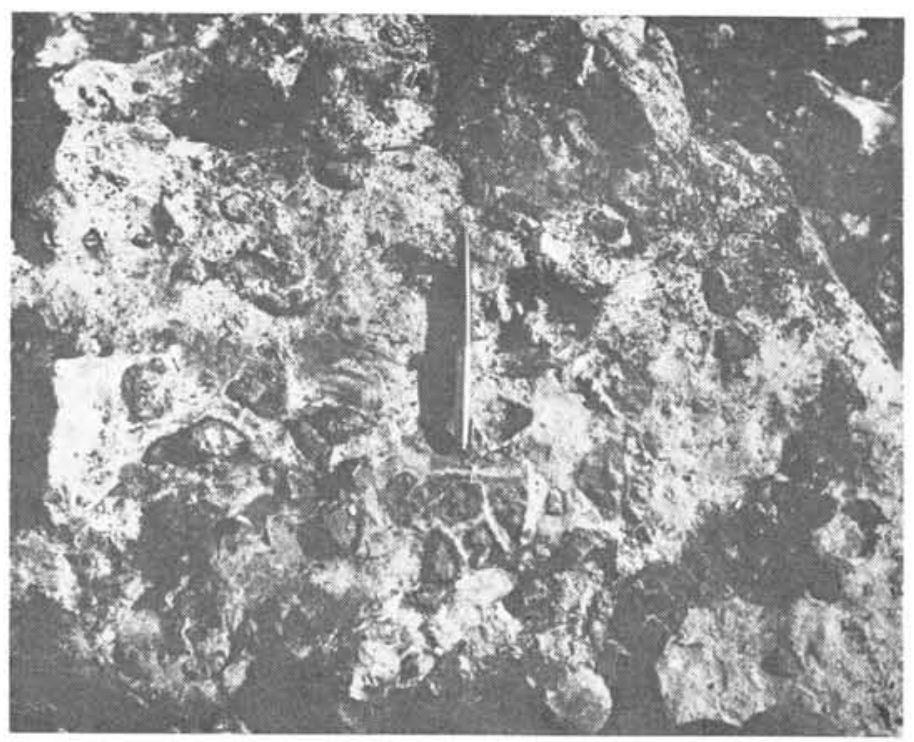

Fig. 3 - "Brecciated" aspect of the calcrete deposits due to the strong angularity of the sandy "spots" (Borebi. State of São Paulol.

Fig. 4 - Nodular calcrete scattered within clayey calciferous sandstone of the Marflia Formation (Bauru - Santa Cruz do Rio Pardo highway, State of São Paulol.

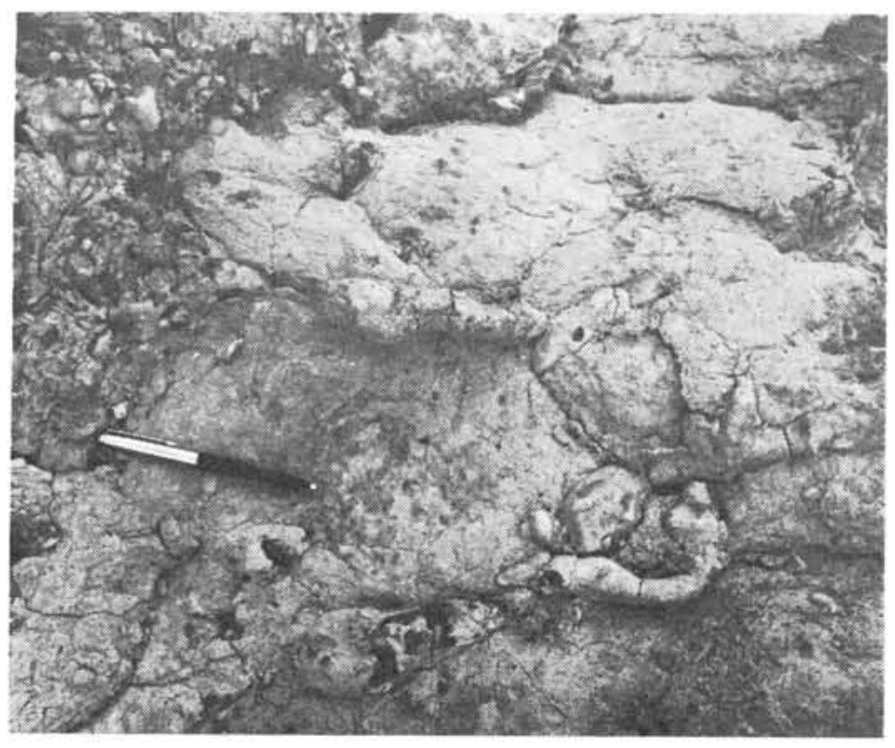

a) Homogeneous limestone - Unmottled, very pure, micritic limestone, characterized by light colours generally between grayish pink (10R 8/2) and very pale orange (10YR $8 / 2)$.

b) Brecciated limestone - It is possible to distinguish two subtypes, both characterized by a mottled pattern. The first one, made up by angular pockets of sandy (quartzose) sediment ("sand pocket") separated by homogeneous limestone. This feature is also visible on a microscopic scale. The second type comprises angular homogeneous limestone fragments separated by sandy limestone.

c) Conglomeratic limestone - This occurs as lenses of $\mathrm{CaCO}_{3}$ - cemented conglomerates within purer limestones. The clasts, which range from granules to pebbles (to more than $5 \mathrm{~cm}$ ), consist of quartz, quartzite and chert.

d) Sandy limestone - This is commonest and most varied limestone type, ranging from purer sandy limestones to $\mathrm{CaCO}_{3}-$ cemented sandstones.

e) Silicified limestone - In general the 
limey portions are characterized by light colours (pinkish gray $=5 Y \mathrm{R} 8 / 1$ ) and the silicified portions by dark colours (medium gray $=\mathrm{N} 5$ to dark gray $=\mathrm{N} 4)$. The contact between these portions is very irregular.

\section{MICROSCOPIC DESCRIPTION}

Ninety-five thin sections of 72 calcrete samples were examined microscopically. Some of the textural and structural details, visible only under the microscope, were very important in both petrologic description and in the identification of the calcretes.

\section{Textural aspects}

Description of textural aspects is here limited to calcite crystallinity, calcite crystalline habit and grain size of insoluble residues.

a) Calcite crystal size - Crystal sizes vary from cryptocrystalline, where individual calcite crystals are not resolvable even at magnifications of $320 \mathrm{X}$, to $0.60-0.80 \mathrm{~mm}$ and, in veins and druses, more than $1 \mathrm{~mm}$. Even in a restricted area of a thin section, variation in crystallinity is a rule, and uniformity an exception (Fig. 5). However, apparent crystal size classes occur between 0.002 and $0.005,0.005$ and $0.010 \mathrm{~mm}, 0.040$ and 0.100 $\mathrm{mm}$, and 0.200 and $0.400 \mathrm{~mm}$ (Fig. 6).

Fig. 5 - Varied calcite crystallinity (calcrete from a quarry in Ponte Alta, Uberaba area, State of Minas Gerais).

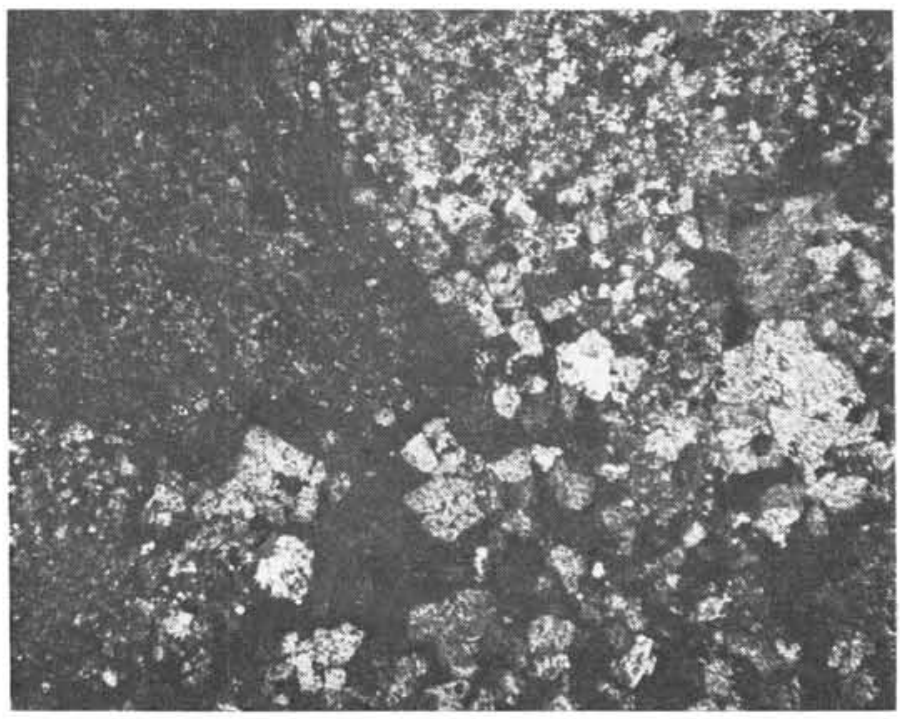

There is a relationship between calcite crystallinity and other microscopical features. For example, cryptocrystalline calcite portions may exhibit pisolitic and alveolar structures. These primary structures possibly are not visible in more coarsely crystalline portions (sparry calcite) due to their obliteration during diagenetic recrystallization. The common association of clay in the cryptocrystalline portions of the Bauru limestones suggests that calcite crystal growth during diagenesis may have been inhibited by this mineral, a common phenomenon observed elsewhere in limestones submitted to incipient diagenesis (MARSCHNER, 1968:55).

b) Calcite crystal habit - In cryptocrystalline calcite crystal outlines are not visible even under $320 \mathrm{X}$ magnification. In coarser

portions the calcite crystals exhibit very distinct outlines and striated surfaces, and comprise a mosaic of more or less equidimensional crystals. The striations are attributed to crystal cleavage. The crystalline mosaic is frequently interrupted by coarser crystalline veins or by finer grained spots (Fig. 5). In general the calcite crystals are sharply penetrated each other.

c) Grain size of insoluble residues - Only the sandy and silty microscopic insoluble residues, predominantly falling within 0.030 to $0.060 \mathrm{~mm}$ and 0.200 to $0.500 \mathrm{~mm}$ intervals (Fig. 7), have been considered. Eight thin sections were completely free of sandy and coarse-silty insoluble residues, indicating that the Marilia Formation limestones are locally very pure. 


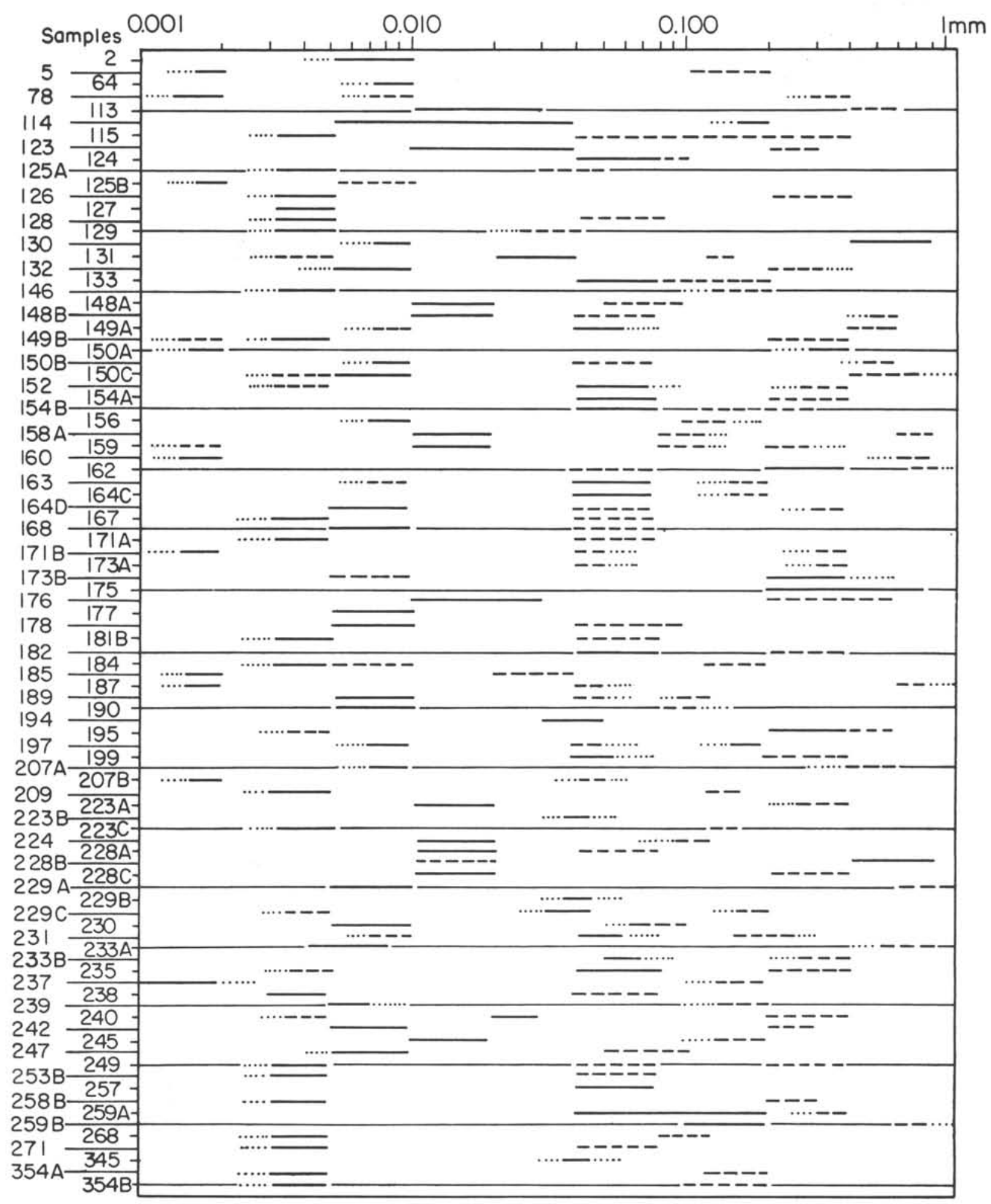

Fig. 6 - Some calcite crystallinity intervals in the Marilia Formation calcretes: $0.002-0.005 \mathrm{~mm}$, $0.005-0.010 \mathrm{~mm}, 0.040-0.100 \mathrm{~mm}$ and $0.200-0.400 \mathrm{~mm}$. 


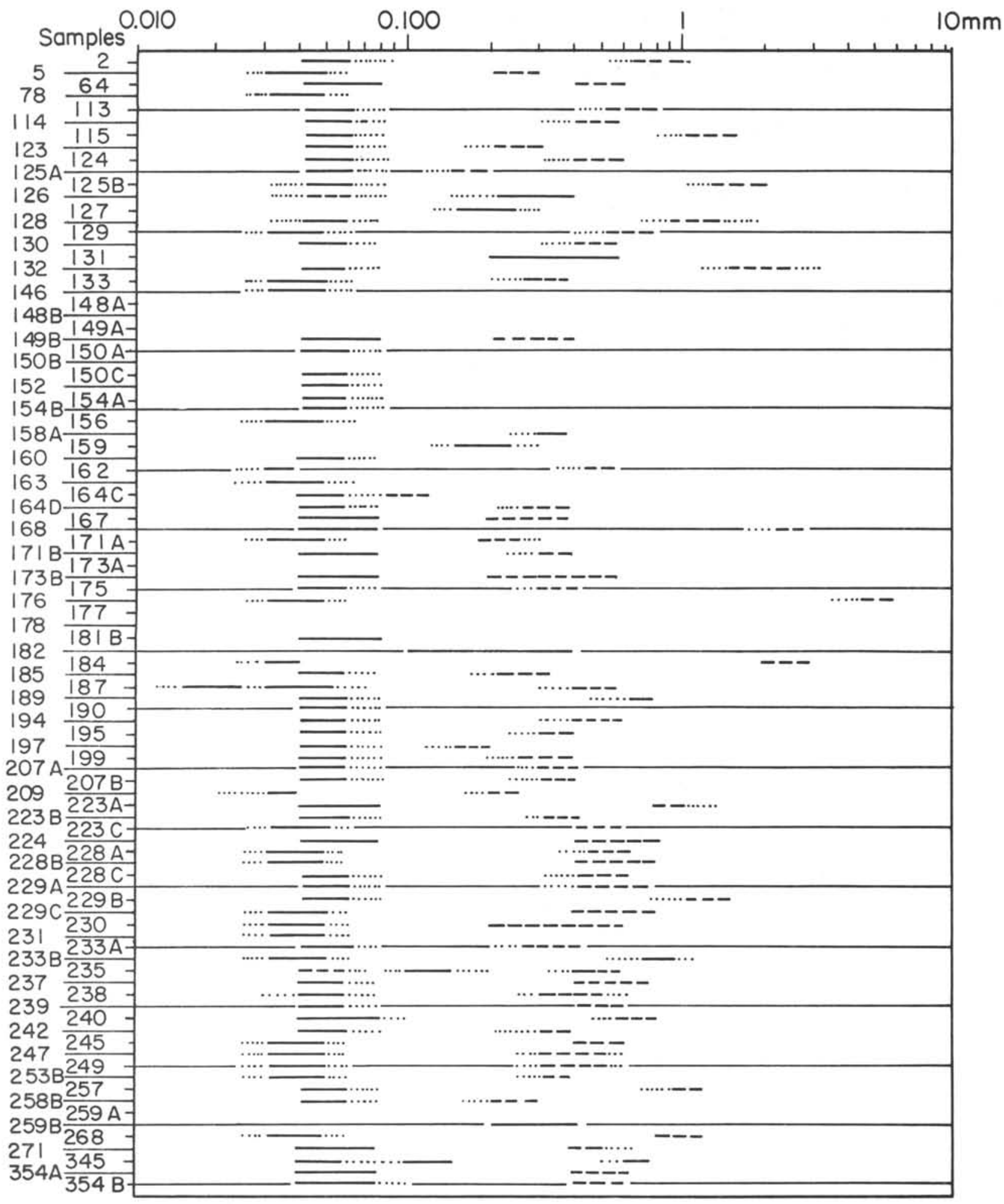

Fig. 7 - Insoluble residues grain sizes predominantly consisting of the $0.030-0.060$ and $0.200-$ $0.500 \mathrm{~mm}$ intervals, Marflia Formation calcretes. 


\section{Structural aspects}

Microscopic structures recognized in thin sections include silicification structures, vugs and druses, laminar structures, pisolitic and alveolar structures, "sand pockets", sand grains and chalcedony with calcite halos, microporosity, and corroded detrital grains.

a) Silicification structures - Fifty-six thin sections, mostly from the Uberaba area, presented silicification structures evidenced either by very restricted silicification nuclei or by the generalized transformation of calcite into fibrous chalcedony, partially recrystallized into quartz. It seems that silicification preferentially occurs within portions characterized by abundant fragments of quartz and quartzite. According to WALKER (1960), the intimate relationship between silicification and calcretes suggests that the major source of silica is that released during the replacement of silicates by calcite.

b) Vugs and druses - Vugs and druses, as well as geodes, are very characteristic features of these calcretes, having been found in 43 of the thin sections. They show varied shapes and sizes, and occasional geopetal filling by sparry calcite or fibrous chalcedony. Silicification features are commonlv associated with spar-filled voids exhibiting coarser crystallinity.

c) Laminar features - Laminar structures are observed in a dense micritic limestone with crystals 0.005 to about $0010 \mathrm{~mm}$ in diameter. The laminae average 0.1 to $0.4 \mathrm{~mm}$ in thickness and have slight undulating boundaries. Such features, similar to the "algal coating" mentioned by MÜLLER-JUNGBLUTH (1968), were identified in 42 of the thin sections.

d) Pisolitic and alveolar structures - The pisolitic structures are spherical or elliptical and characterized by insoluble nuclei. The laminae are concentric and the outer surface is smooth or undulatory. Pisolitic structures frequently develop in a vadose environment (DUNHAM, 1969).

In many places, alveolar structures, 0.80 to $2 \mathrm{~mm}$ in diameter, are well developed in the laminar unit as flatened rhizocretions with many insoluble residues. SUGUIO (1973) records the presence of frequent alveolar structures within the Mangabeira quarry near the Uberaba - Uberlândia Federal Highway (Fig. 8).

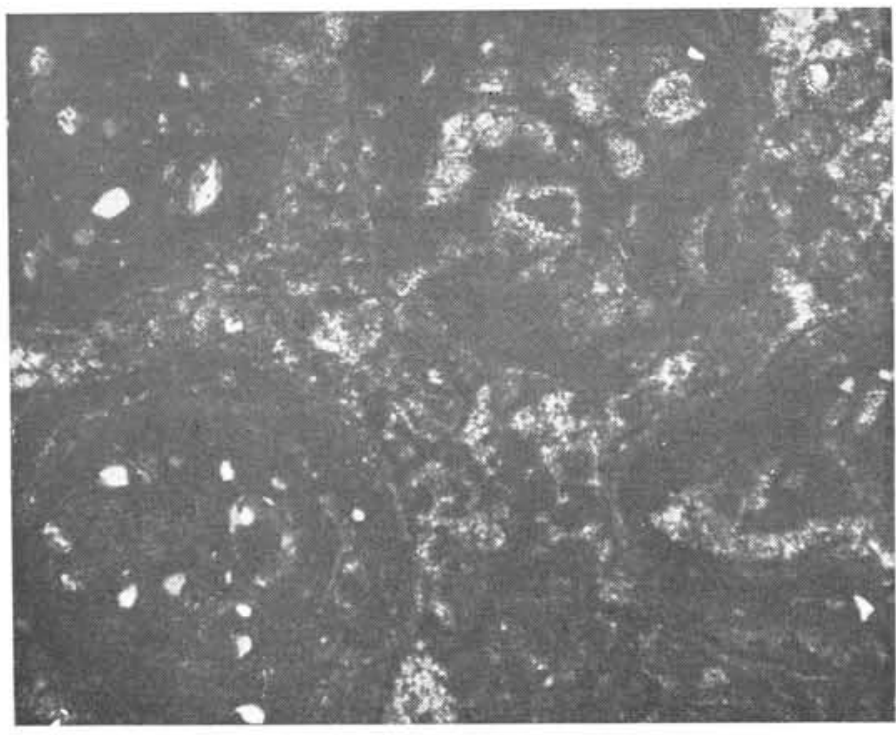

Fig. 8-Alveolar structure with many insoluble residue nuclei, probably representing rhizocretions (Mangabeira quarry) BR-050 highway between Uberaba and Uberlândia, State of Minas Gerais. e) "Sand pockets" - These features associated with abnormal concentrations of sand-sized (0.04 to $0.08 \mathrm{~mm})$, insoluble clastic residues (quartz, quartzite, feldspar, etc.) contained within "sand pockets" a few mm to several $\mathrm{cm}$ in diameter. This structure, 
present in at least 15 thin sections, probably developed through the concentration of these residues associated with segregation phenomena during the diagenetic recrystallization, penecontemporaneous with sedimentation.

f) Sand grains and chalcedony with calcite halos - Insoluble san grains and chalcedony are frequently enveloped by a halo of sparry syntaxial calcite crystals. This feature is easier to see when surrounded by cryptocrystalline calcite.

g) Microsporosity - Tiny voids of varied shapes and sizes have been seen in 7 thin sections. In some cases they are solution voids and, in other cases, they represent the spaces left within voids partially filled by spar.

h) Corroded detrital grains - Detrital silicate minerals are corroded by calcite so that grain edges are strongly indented. Quartzite fragments have apparently been more affected than detrital quartz grains, due to the preferential replacement along crystal boundaries within the quartzite. As silica shows an inverse solubility relationship with calcite (CORRENS, 1950), this corrosion phenomenon, evident in at least 6 thin sections, may well have occurred when the $\mathrm{pH}$ was above 9 (ALEXANDER, et al., 1954), where calcite begins to precipitate and silica begins to dissolve.

\section{Insoluble residues}

Insoluble residues of the calcretes, consisting both of detrital and non-detrital (authigenic) silicate minerals, were isolated into two size fractions, i.e., finer than $0.062 \mathrm{~mm}$ (silt and clay) and coarser than $0.062 \mathrm{~mm}$ (sand).

Percentage of $\mathrm{CaCO}_{3}$ and insoluble residues - Ten of the 112 samples are not called limestones, but rather calcareous sandstones, with $\mathrm{CaCO}_{3}$ contents lower than $50 \%$ (Table I, Fig. 9 and 10).

From the Table I it is evident that the average compositions in insoluble residues of the calcrete samples in Uberaba area are quite similar, both in outcrop samples and in drill cores. Locally, however, these limestones can consist of more than $99 \% \mathrm{CaCO}_{3}$ samples, showing probable lacustrine origin. On the other hand, the average composition of calcrete samples from Frutal and Prata (State of Minas
Gerais) and Rio Verde (State of Goiás) show lower $\mathrm{CaCO}_{3}$ content and consequently more insoluble residues than in the Uberaba area.

The calcrete samples from the Agudos (State of São Paulo) show an average $\mathrm{CaCO}_{3}$ composition lower than that of the Uberaba area. with a corresponding increase in the sandy insoluble residue content and decrease in the clayey-silty insoluble residue. The calcrete nodules, also from the State of São Paulo, show the lowest $\mathrm{CaCO}_{3}$ values of the analysed samples. Nevertheless, they may still be considered as limestones, as they have more than $50 \% \mathrm{CaCO}_{3}$. They are, however, as sandy as Agudos area calcretes and have a higher silt and clay content.

In summary, the Marilia Formation calcretes are, in general, purer and more extensively developed in the Uberaba area, where no significant difference could be detected between surface and subsurface samples. On the other hand. where the calcrete's $\mathrm{CaCO}_{3}$ content is high, its silt and clay content is also relatively high with respect to its sand content, a common relationship in calcretes (GOUDIE, 1973:25).

Mineralogical composition of insoluble residues - Sand-sized insoluble residues (coarser than $0.062 \mathrm{~mm}$ ), consist predominantly of quartz grains. Heavy minerals, quartzite fragments, feldspar, and other forms of authigenic silica (e.g. chalcedony) are less important.

Clay minerals in the silt and clay fractions have been identified by X-ray diffraction analysis of 35 samples from the Uberaba, 10 from drill cores of the Ponte Alta, 10 from west of Uberaba (Frutal, etc.), 11 from the Agudos, and 23 from calcrete nodules mentioned previously (Fig. 11). Following are some of the conclusions from these analyses:

a) There are seven types of clay minerals: attapulgite (also known as palygorskite), illite, kaolinite, chlorite, montmorillonite (also known as smectite); sepiolite and vermiculite have been questionably identified in some of the samples. This suite of clay minerals is practically the same as that found by WATTS (1980:668) in Kalahari calcretes.

b) Attapulgite and illite are the dominant clays of the analysed samples, the former represented in 45 samples, the latter in 43 samples; in 30 of these samples the two minerals occurred together. Attapulgite is considered 


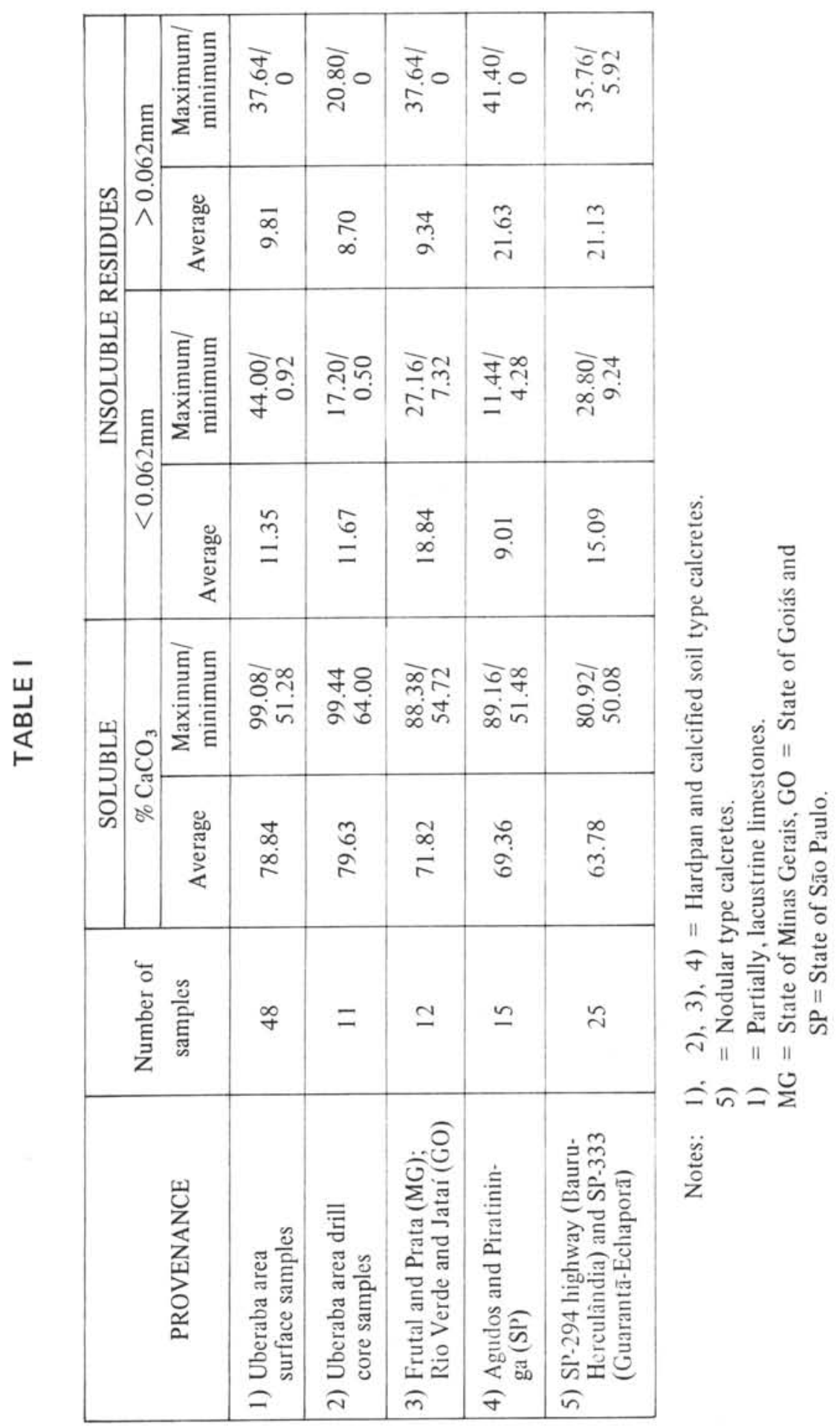




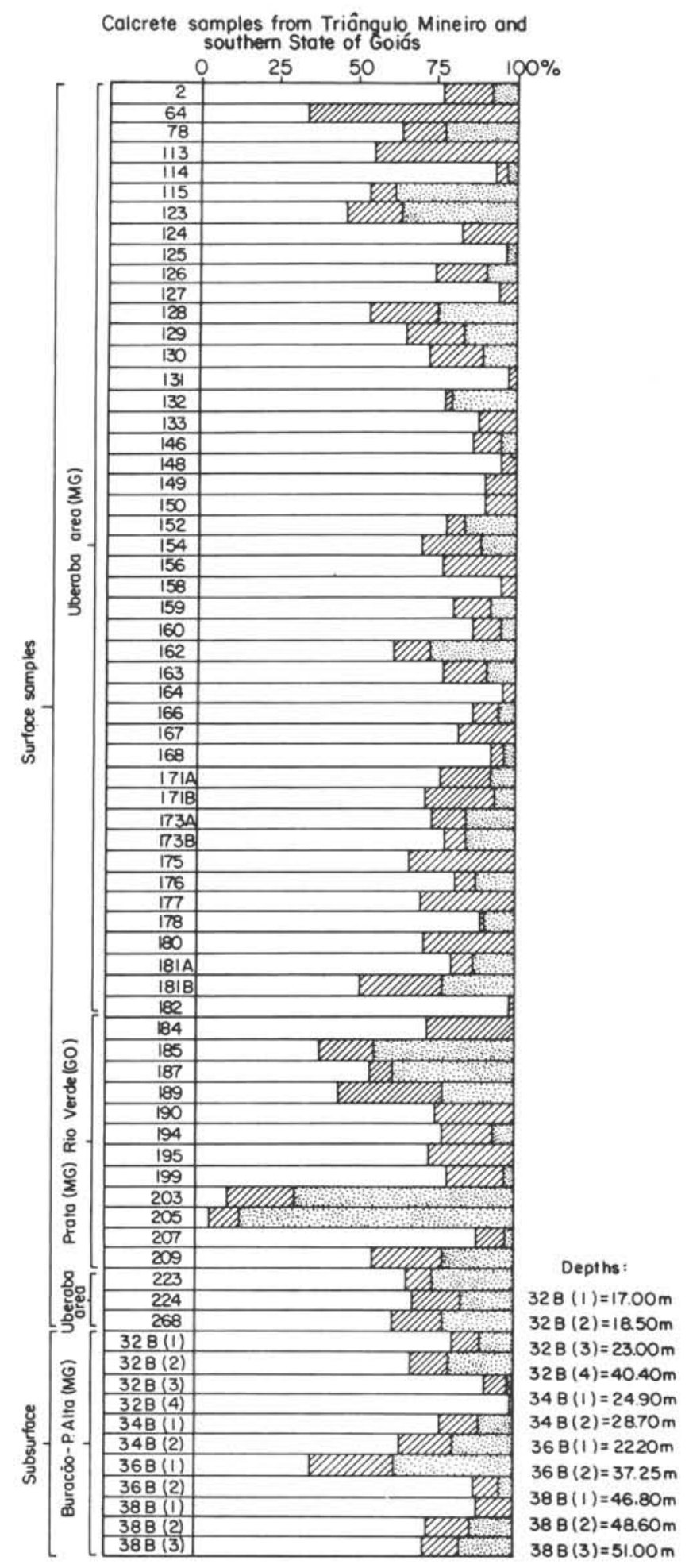

Fig. 9 - Size frequency of insoluble residues in samples of calcretes from the Triångulo Mineiro and southern State of Goiás. 
Calcrete samples from State of Sāo Paulo

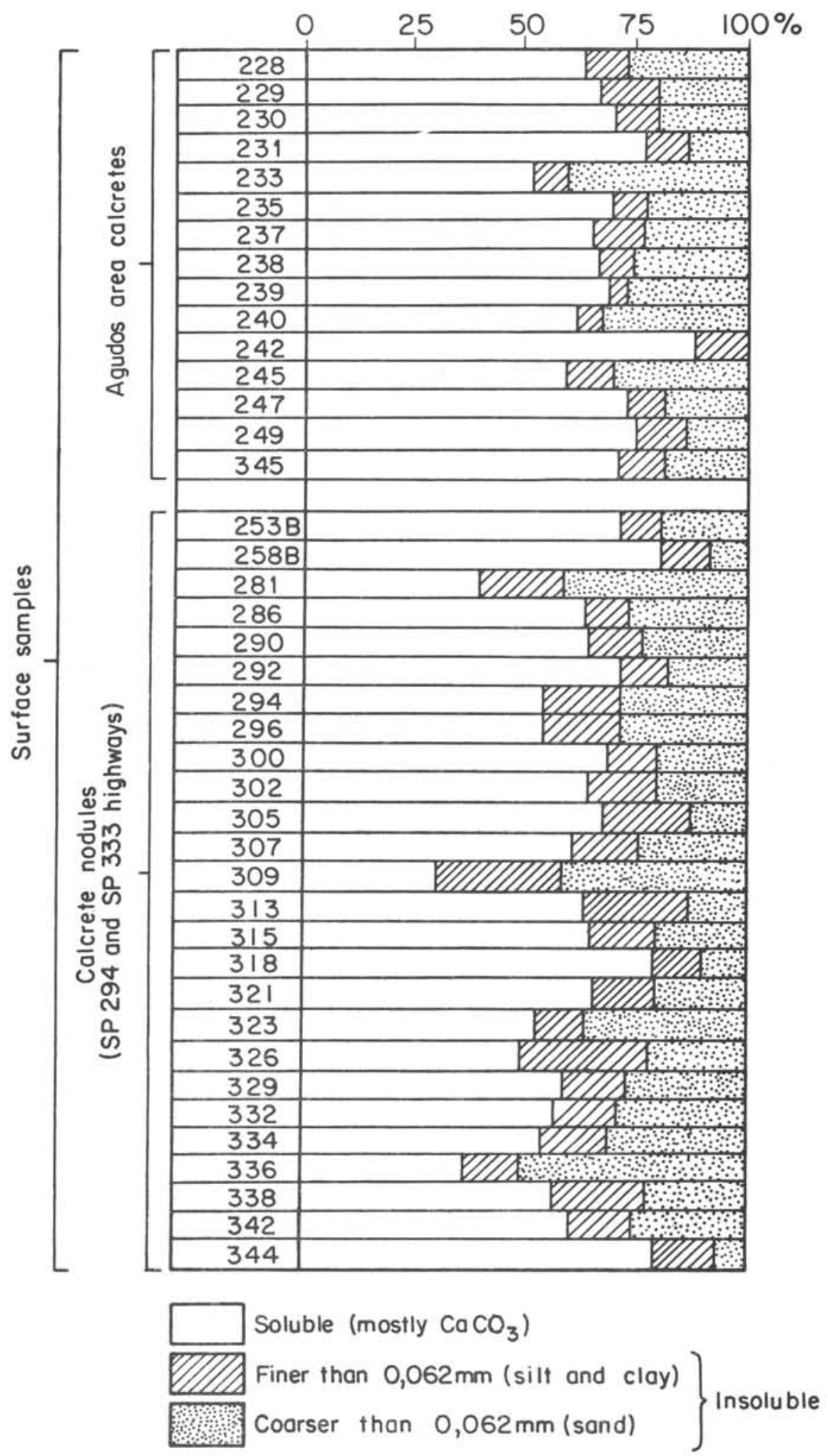

Fig. 10 - Size frequency of insoluble residues in samples of calcretes from the Agudos and other regions of the State of São Paulo. 
a typical authigenic silicate frequently identified within modern and ancient calcretes (GARDNER, 1972, NAHON and RUELLAN, 1975 and REEVES, 1976), and in other semiarid soils (BLOM, 1970 and GUPTA and RAYCHAUDHURI, 1973).

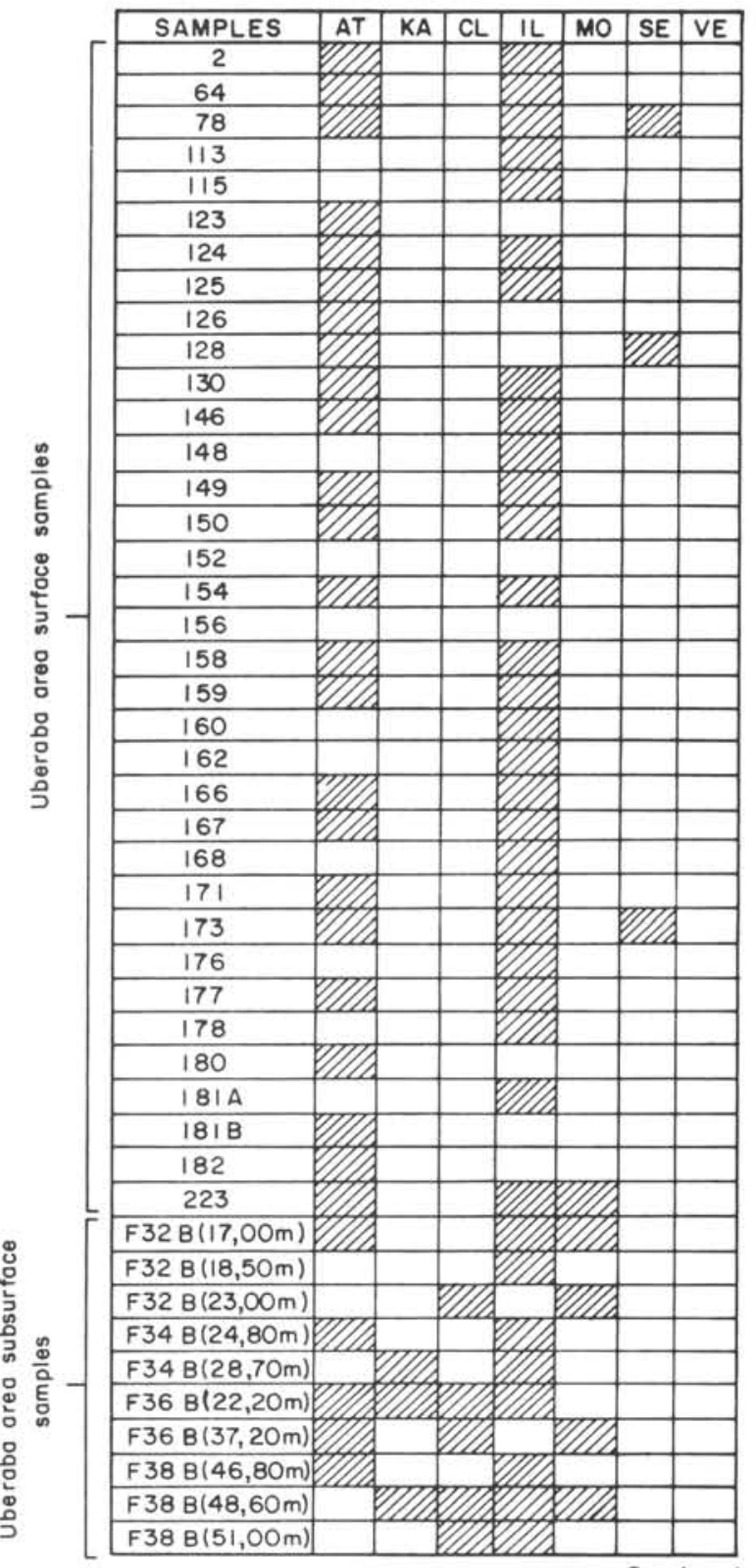

A c) In the Uberaba area, the surface samples clay mineralogy was more constant than in the subsurface samples. In the State of São Paulo, clay mineralogy was more variable in the calcrete nodules than in the sandy calcretes (calcified soils).

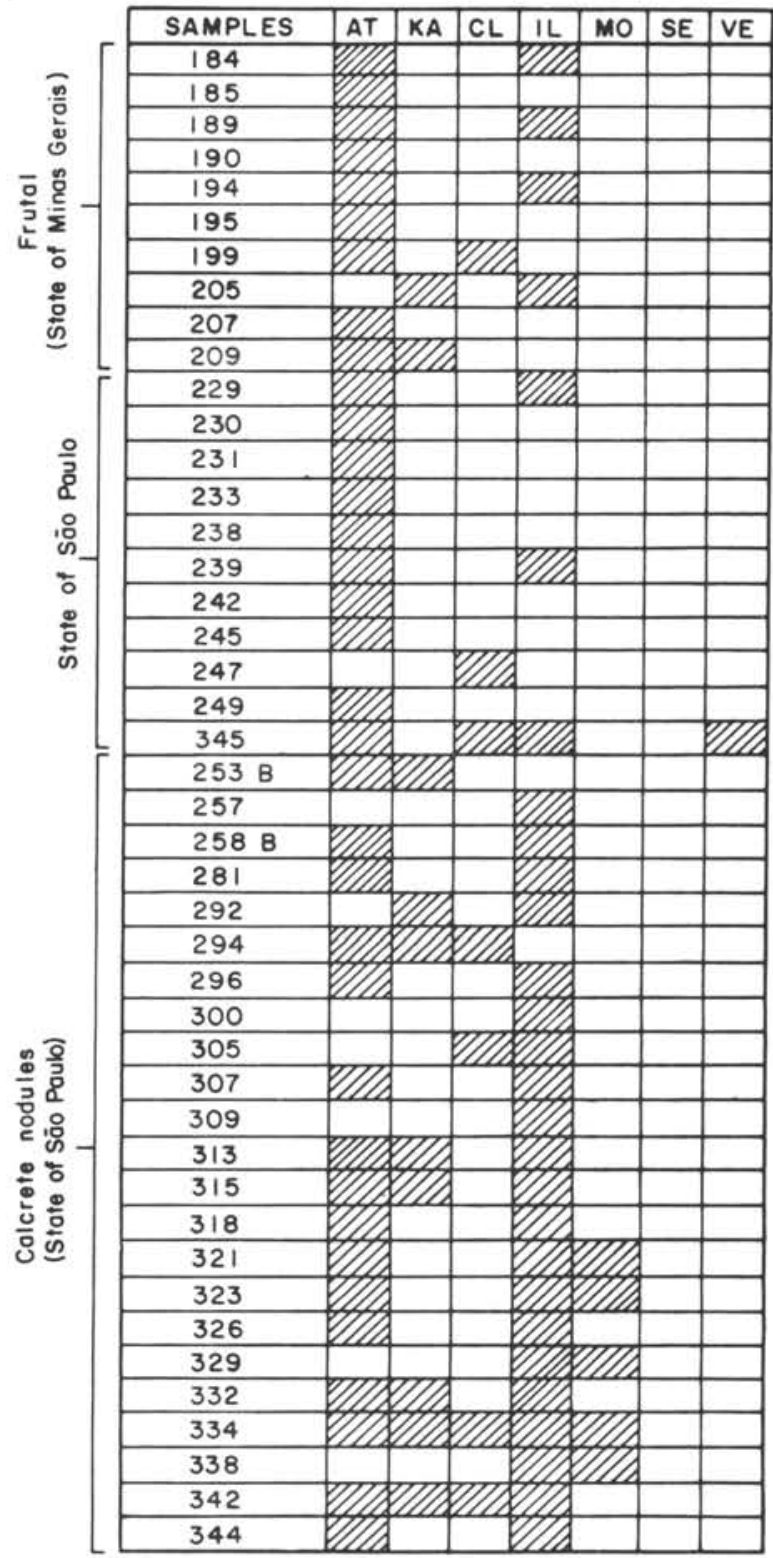

B

Fig. 11 - Clay mineral composition of the insoluble residues from calcrete samples of the Marilia Formation. $\mathrm{AT}=$ attalpugite; $\mathrm{KA}=$ kaolinite; $\mathrm{CL}=$ chlorite; $\mathrm{IL}=$ illite; $\mathrm{MO}=$ montmorillonite; $\mathrm{SE}=$ sepiolite and $\mathrm{VE}=$ ver miculite.

\section{CONCLUSIONS}

General features observed in the field, together with laboratory data, indicate that majority of the Bauru Group carbonates are undoubtedly calcretes. Practically all featu- res listed by GOUDIE (1975:4) as calcrete recognition criteria have been identified within these limestones.

The purer limestone found near Ponte Alta could have been formed under a semi-arid climate within ephemeral playa lakes. This 
SUGUIO, K. \& BARCELOS, J.H.

limestone is associated with hardpan calcretes with a total thickness of about $8 \mathrm{~m}$. Except for this occurrence, there is no lacustrine limestone within the Marilia Formation. Rather, practically the entire thickness of this formation can be classified as calcified soils or nodular calcretes. In this case, the maximum thickness of the calcrete deposits of the Marilia plateau is more than $200 \mathrm{~m}$, thus representing the thickest such deposit in the world.

Some periods during the sedimentation of the Adamantina Formation (also within the Bauru Group) were also characterized by a semi-arid paleoclimate, as evidenced by the extensive distribution within this formation of nodular calcretes and calcified soils, similar to those of the Marilia Formation.
Bol. IG, Instituto de Geociências, USP, V. 14:31-47, 1983

Without excluding Ca-bearing minerals in underlying basaltic rocks as a possible source of the calcium carbonate for the Bauru Group calcretes (especially for the Marilia Formation), the extensive development of the $\mathrm{CaCO}_{3}$ rich deposits in the Uberaba area may be more readly explainable if one assumes a substantial contribution of carbonate from the nearby Precambrian Bambui Group limestones. This argument may also explain the absence of pure limestones in other areas, as in the State of São Paulo, where Precambrian limestones apparently do not occur nearby, either in stratigraphic or in geographic terms.

The authors wish to express their sincere gratitude to Dr. Thomas R. Fairchild of the University of São Paulo for careful revision of the English text.

\section{REFERENCES}

ADAMS, A.E. - 1980 - Calcrete profiles in the Eyam Limestone (Carboniferous) of Derbyshire: petrology and regional significance. Sedimentology, v, 27:651-660

ALEXANDER, G.B., HESTON, G.M. and ILER, H.K. - 1954 - The solubility of amorphous silica in water. J. Phys. Chem., v. 58:453-455.

ALMEIDA, F.F.M. de and BARBOSA, O. - 1953 - Geologia das quadrículas de Piracicaba e Rio Claro, Estado de São Paulo. DNPM/DFPM, Bol. 143:96 p.

BARBOSA. O., BRAUN, O.P.G., DYER, R. C. and CUNHA, C.A.R. - 1970 - Geologia da região do Triângulo Mineiro. DNPM/DFPM, Bol. 136:140 p.

BARCELOS, J.H., LANDIM, P.M.B. and SUGUIO, K. - 1981 - Análise estratigráfica das seqüências cretáceas do Triângulo Mineiro (MG) e suas correlações com as do Estado de São Paulo. 3a Simpósio de Geologia Regional, Sociedade Brasileira de Geologia, Núcleo de São Paulo, Atas v. 2:90-102.

BLANK, H.R. and TYNES, E.W. - 1965 - Formation of caliche in situ. Geol. Soc. America Bull., v. 76:1387-1392.

BLOM, G.I. - 1970 - Buried palygorskite soils in the Lower Triassic of the Moscow sineclise. Dokl. (Proc.) Acad. U.S.S.R., Earth Sci. Sect., 194:52-54.

CORRENS, C.W. - 1950 - Zur geochemie der diagenese. Geochim. Cosmochim. Acta, v. 1:49-54.

DAVIDSON, W.A. - 1968 - Millstream hydrogeological investigation. Dept. of Mines, Western Australia, Annual Report: $57-62$.

DUNHAM, R.J. - 1969 - Vadose pisolite in the Capitan Reef (Permian), New Mexico and Texas. In: Friedman, G.M., ed., Depositional environments in carbonate rocks. Soc. Econ. Paleontologists and Mineralogists, Spec. Publ. 14:182-191.

ELIAS, M.K. - 1948 - Ogallala and post Ogallala sediments. Geol. Soc. Amer. Bull., v. 59:609-612.

GARDNER, L.R. - 1972 - Origin of the Mormon Mesa caliche, Clark County, Nevada. Geol. Soc. Amer. Bull. v. $83: 143-156$

GOUDIE, A.S. - 1973 - Duricrusts in Tropical and Subtropical landscapes. Claredon Press, Oxford: 174 p.

GOUDIE, A.S. - 1975 - Petrographic characteristics of calcretes (caliches): modern analogues of ancient cornstones. In: Vogt, T., ed., Colloque: Types de croûtes calcaires et leur répartition régionale: 3-6. Strasbourg.

GUPTA, R.D. and RAYCHAUDHURI, S.P. - 1973 - Clay minerals in different groups of soils in India and factors affecting their genesis. Technology, India, v. 10:333-338. 
JAMES, N.P. - 1972 - Holocene and Pleistocene calcareous crust (caliche) profiles: criteria for subaerial exposure. Journal of Sedimentary Petrology, v. 42:817-836.

KENDALL, C.G. St. C. - 1969 - An environmental re-interpretation of the Permian evaporite/carbonate shelf sediments of the Guadalupe Mountains. Geol. Soc. Amer. Bull., v. 80:2503-2526.

KLAPPA, C.F. - 1980 - Rhizocretions in terrestrial carbonates: classification, recognition, genesis and significance. Sedimentology, v. 27:613-629.

MARSCHNER, H. - 1968 - Relationship between carbonate grain size and non-carbonate content in carbonate sedimentary rocks. In: Müller, G. and Friedman, G.M., eds., Recent developments in carbonate sedimentology in Central Europe, Springer-Verlag, Berlin.

MüLLER-JUNGBLUTH, W.U. - 1968 - Sedimentary petrologic investigation of the Upper Triassic "Hauptdolomit" of the Lechtaler Alps, Tyrol, Austria. In: Müller, G. and Friedman, G.M., eds., Recent developments in carbonate sedimentology in Central Europe, Springer-Verlag, Berlin.

MULTER, H.G. and HOFFMEISTER, J.E. - 1968 - Subaerial laminated crusts of the Florida Keys. Geol. Soc. Amer. Bull., v. 79:182-192.

NAGTEGAAL, P.J.C. - 1969 - Microtextures in recent and fossil caliche. Leidsche geologische mededeelingen, v. 42:131-142.

NAHON, D. and RUELLAN, A. - 1975 - Les accumulations de calcaires sur les marnes Eocènes de la falaise de Thies (Sénégal). Mise en évidence des phénomènes d'épigénie. In: Vogt, T., ed., Colloque: Types de croûtes calcaires et leur répartition régionale: 7-11, Strasbourg.

NETTERBERG, F. - 1967 - Some road making properties of South African calcretes. Proc. $4^{\text {th }}$ Reg. Conf. Africa Soil Mech. Fndn. Engng., Cape Town, v. 1:77-81.

REEVES, C.C. JR. - 1976 - Origin, classification and geologic history of caliche of the southern High Plains, Texas and eastern New Mexico. J. Geology, v. 78:352-362.

REEVES, C.C. JR. - 1970 - Caliche: Origin, classification, morphology and uses. Estacado books, Texas.

ROTHROCK, E.P. - 1925 - On the force of crystallisation of calcite. J. Geology, v. 33:80-82.

SOARES, P.C., LANDIM, P.M.B., FULFARO, V.J. and SOBREIRO NETO, A.F. - 1980 - Ensaio de caracterização estratigráfica do Cretáceo do Estado de São Paulo: Grupo Bauru, Revista Brasileira de Geociências, v. 10:177185 .

SUGUIO, K. - 1973 - Formação Bauru: calcários e sedimentos detríticos associados. Tese de Livre Docência, Instituto de Geociências, Universidade de São Paulo, 2 v., 236p. + ill., São Paulo.

SUGUIO, K. and BARCELOS, J.H. - 1978 - Nota sobre a ocorrência de atapulgita em sedimentos do Grupo Bauru, Cretáceo Superior da Bacia do Paraná. Anais do XXX Congr. Brasileiro de Geologia, v. 3:1170-1179.

SUGUIO, K. and BARCELOS, J.H. - 1980 - Significados paleoclimáticos e paleoambientais das rochas calcárias da Formação Caatinga (BA) e do Grupo Bauru (MG/SP). Anais XXXI Congr. Brasileiro de Geologia, v. 1: 607-617.

SUGUIO, K., BERENHOLC, M. and SALATI, E. - 1975 - Composição química e isotópica dos calcários e ambiente de sedimentação da Formação Bauru. Bol. IG, Instituto de Geociências, USP, v. 6:55-75.

SWINEFORD, A., FRYE, J.C. and LEONARD, A.B. - 1958 - Petrology of the Pliocene pisolitic limestone in the Great Plains. Kansas Geol. Survey Bull., v. 130:97-116.

YOUNG, R.G. - 1964 - Fracturing of sandstone cobbles in caliche cemented terrace gravels. Journal of Sedimentary Petrology, v. 34:886-889.

WALKER, T.R. - 1960 - Carbonate replacement of detrital crystalline silicate minerals as a source of authigenic minerals in sedimentary rocks. Geol. Soc. Amer. Bull., v. 71:145-152.

WATTS, N.L. - 1980 - Quaternary pedogenic calcretes from the Kalahari (southern Africa): mineralogy, genesis and diagenesis. Sedimentology, v. 27:661-686. 